\title{
ALTERNATION OF GENERATIONS IN A COCCOLITHOPHORID, CRICOSPHAERA CARTERAE (BRAARUD \& FAGERL.) BRAARUD
}

\author{
By D. G. RAYNS \\ The Plymouth Laboratory \\ (With Plates I and II)
}

The purpose of the present investigation is primarily to determine whether or not there is a chromosomal alternation of generations in the coccolithophorid, Cricosphaera carterae (Braarud \& Fagerl.) Braarud (I960). This is a logical step following the demonstration of a dimorphic life-cycle in this species (Parke, I96I). Although the life-cycle is basically dimorphic, the non-motile phase exhibits a range of form, which includes Chrysonema-, Gloeochrysis-, Apistonema- and Chrysotila-like stages (Parke, 196r).

\section{MATERIAL AND METHODS}

The material used in this investigation is from Plymouth culture no. I8I referred to $C$. carterae. The culture methods are those of Parke, Manton \& Clarke (I955).

An examination of the nuclear cytology was conducted as follows. Fixations were made in acetic alcohol in the ratio I part glacial acetic acid to 3 parts $95 \%$ alcohol. Best results were obtained when the material was subjected to mordanting. The mordant, ferric acetate, was incorporated in the fixative, the glacial acetic acid being saturated with the ferric salt (Thomas, 1940). The material to be fixed was concentrated by centrifugation, the culture solution decanted, and the fixative added. The material was stored for $24 \mathrm{~h}$ during which time the acid in the fixative dissolved the calcareous coccoliths, which would otherwise interfere with the preparations. Staining was carried out by the acetocarmine method as used for the colonial Volvocales (Cave \& Pocock, I95I). Preparations were rendered permanent in 'Euparal' (Godward, I948).

\section{OBSERVATIONS}

Fixations of the motile phase in young cultures were made. These yielded mitotic figures of all stages of the nuclear cycle (Pl. I, figs. I-4).

The interphase nucleus (Pl. I, fig. I) shows a strongly acetocarmine positive reticulum surrounding a relatively large nucleolus. As such preparations are 
subjected to squashing, it is not possible to make absolute measurements of spheroidal bodies such as interphase nuclei and nucleoli. At the prophase stage (Pl. I, fig. 2) the nucleolus disappears and the interphase reticulum becomes organized into distinct chromosomes, which are clearly double, being composed of pairs of chromatids. The position of the centromere is not visible. At this stage, the chromosomes are between 0.8 and $\mathrm{I} \cdot 2 \mu$ long.

Throughout prophase, the chromosomes shorten and broaden until metaphase is reached, when the chromosomes become arranged on the spindle equator. A polar view of a metaphase plate is seen in Pl. I, fig. 3. The double nature of each chromosome is no longer visible and the chromosomes, even the longest, have assumed the form of spheroids, which are between 0.3 and $0.7 \mu$ in diameter. The organization of the plate is such that the smaller chromosomes lie towards the centre and the larger towards the periphery, a frequent condition where there is a size range in the chromosome complement (White, 1942). At anaphase the pairs of chromatids separate and move to opposite poles of the spindle. An equatorial view of mid-anaphase is shown in Pl. I, fig. 4. It is not possible to demonstrate whether the centromere is of the localized or the non-localized type, as the chromosomes are too short to show V-formation at early anaphase. A spindle has not been demonstrated in this species, but it is clearly visible (Rayns, unpubl.) in the related Pleurochrysis scherffelii Pringsheim (1955). At telophase the chromosome groups round off and the chromosomes lose their individuality as the nuclei pass into the interphase state. Cytoplasmic cleavage follows nuclear division, and two daughter-cells are formed.

When the culture had aged, the non-motile, benthic phase appeared. Fixations were made of this material and examined for nuclear divisions. The general process of mitosis is identical with that in the motile phase, although mitotic figures are more difficult to observe in this phase since there is a very thick wall present. Pl. I, fig. 5, shows a thick-walled cell containing two interphase nuclei. P1. I, fig. 6, shows a nucleus in mid prophase; the double nature of the chromosomes is visible and the nucleolus is still present. A polar view of a metaphase nucleus is shown in Pl. I, fig. 7 (this is prometaphase as the chromosomes still have appreciable length). Anaphase separation of the chromatids now occurs and nuclear division ends at telophase (Pl. I, fig. 8), when the chromosome groups round off and pass into the interphase state.

\section{DISCUSSION}

By comparing the corresponding mitotic figures in the motile and non-motile phases, it is clear there is a distinct difference in size. The structures are consistently larger in the motile than in the non-motile phase. This suggests that there may be a difference of ploidy, and accordingly chromosome numbers were investigated. With chromosomes of this size, counts are most easily 
made between late prophase and early metaphase. Two levels of a polar view of metaphase in the motile stage are shown in Pl. II, figs. I and 2. From these photographs the number of chromosomes has been estimated at $42 \pm 2$. The chromosome number of the non-motile phase can be estimated from the late prophase stage shown in four levels in Pl. II, figs. 3-6. The number is found to be $2 \mathrm{I} \pm \mathrm{I}$.

Clearly there is an alternation of chromosomal generations which corresponds to the morphological alternation. In Cricosphaera carterae, therefore, the motile phase is diploid and the non-motile phase is haploid.

On becoming non-motile, the flagellate cell produces a tetrad stage from which the benthic phase develops (Parke, I96I). This stage may well be that at which meiosis occurs, although conclusive chromosomal evidence is not yet available. Sexuality has been recorded in the coccolithophorid Ochrosphaera neapolitana (See Schwarz, I932), where meiosis has been demonstrated. Similarly, there is the problem of syngamy. Small, naked, motile cells are released from the benthic phase (Parke, 196I). Further observations are necessary to determine whether or not these swarmers can function as gametes.

This research was undertaken during the tenure of a Development Commission Fellowship.

\section{SUMMARY}

Material of Cricosphaera carterae was examined cytologically with the acetocarmine technique. Nuclear division is similar to that found in higher plants. Investigations showed there to be a chromosomal alternation of generations, which corresponds to the morphological alternation. The motile phase is diploid, $2 n=42 \pm 2$, and the non-motile phase is haploid, $n=2 \mathrm{I} \pm \mathrm{I}$.

\section{REFERENCES}

BRAARUd, T., I960. On the coccolithophorid genus Cricosphaera n.gen. Nytt Mag. Bot., Vol. 8, pp. 21 I-I2.

BRAARUD, T. \& FAGERLAND, E., I946. A coccolithophoride in laboratory culture. Syracosphaera carterae n.sp. Avh. norske VidenskAkad., No. 2, pp. I-IO.

Cave, M. S. \& Pocock, M. A., I95I. The aceto-carmine technic applied to the colonial Volvocales. Stain Tech., Vol. 26, pp. 173-4.

GoDWARD, M. B. E., I948. The iron alum acetocarmine method for algae. Nature, Lond., Vol. I6I, pp. 203-4.

PARKe, M., I96r. Some remarks concerning the Class Chrysophyceae. Brit. phycol. Bull., Vol. 2, pp. 47-55.

Parke, M., Manton, I. \& Clarke, B., 1955. Studies on marine flagellates. II. Three new species of Chrysochromulina. F. mar. biol. Ass. U.K., Vol. 34, pp. 579-609.

PrIngsheIM, E. G., I955. Kleine Mitteilungen über Flagellaten und Algen. I. Algenartige Chrysophyceen in Reinkultur. Arch. Mikrobiol., Bd. 2I, pp. 40I-IO. 
SchwarZ, E., I932. Beiträge zur Entwicklungsgeschichte der Protophyten. IX. Der Formwechsel von Ochrosphaera neapolitana. Arch. Protistenk., Bd. 77, pp. 434-62. Thомаs, P. T., 1940. Acetocarmine technique for fruit material. Stain Tech., Vol. 15, pp. $167-72$.

White, M. J. D., 1942. The Chromosomes. I24 pp. London: Methuen and Co.

EXPLANATION OF PLATES I-II

Photomicrographs of Cricosphaera carterae

Plate I

Figs. 1-4. Diploid mitosis in the motile cell.

Fig. I. Interphase.

Fig. 2. Prophase.

Fig. 3. Metaphase in polar view.

Fig. 4. Anaphase in equatorial view.

Figs. 5-8. Haploid mitosis in the benthic stage.

Fig. 5. Interphase.

Fig. 6. Prophase.

Fig. 7. Metaphase in polar view.

Fig. 8. Telophase in equatorial view.

\section{Plate II}

Figs. I and 2. Polar view of a diploid metaphase plate in two focal levels showing $42 \pm 2$ chromosomes.

Figs. 3-6. Haploid prophase in four focal levels, showing $2 \mathrm{I} \pm \mathrm{I}$ chromosomes. 

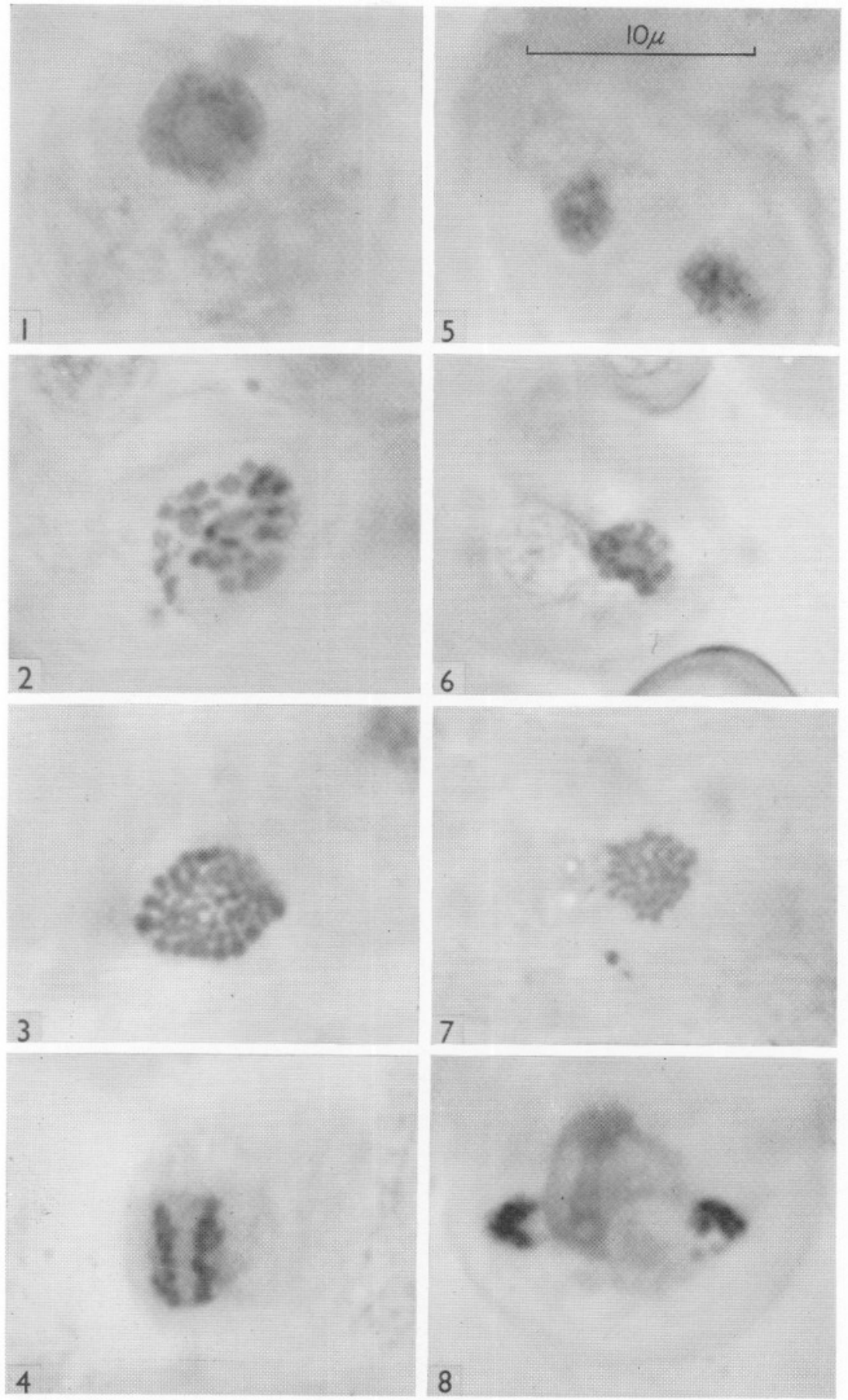

(Facing p. 484) 


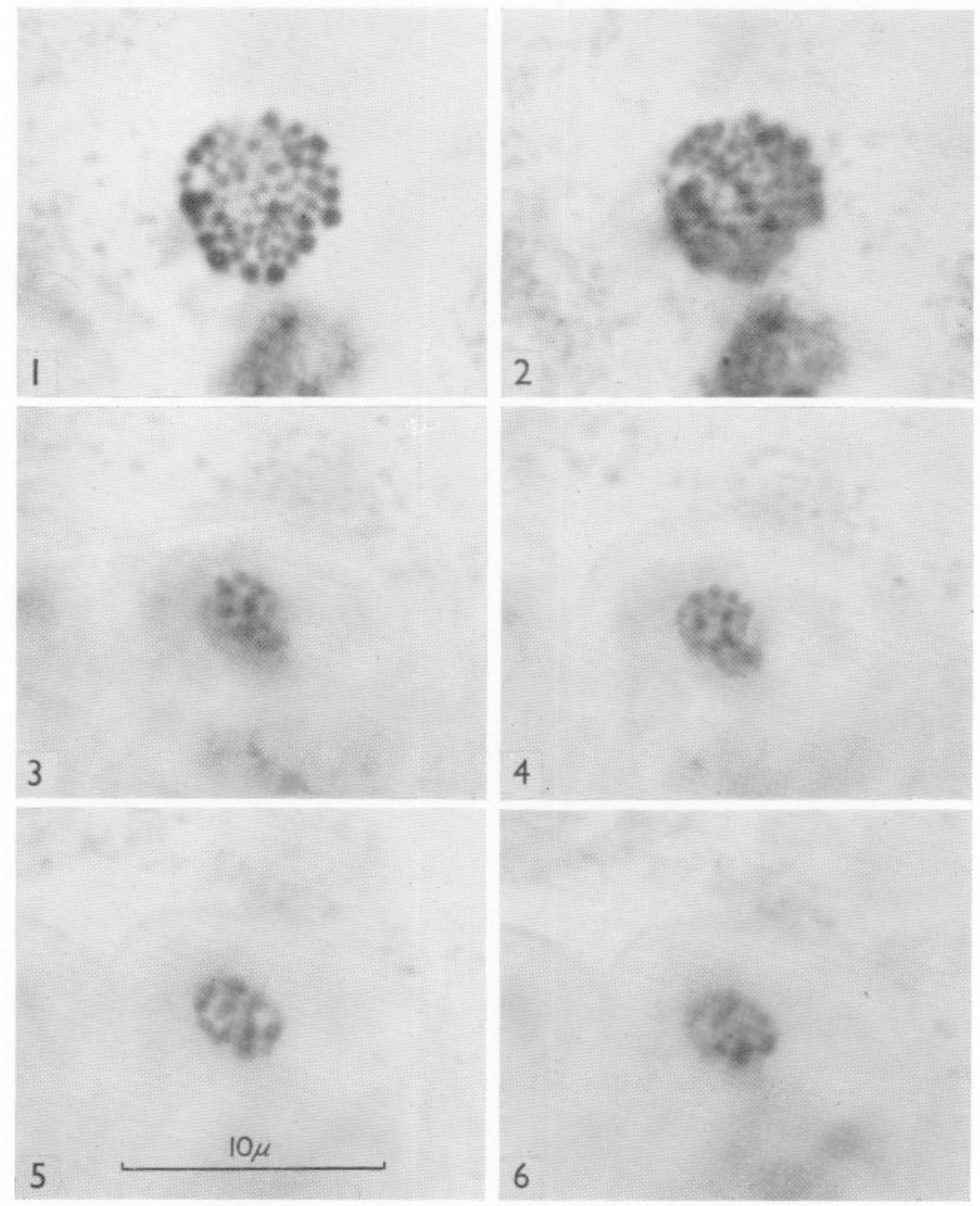

